\title{
Improved prognosis for elderly patients with metastatic renal cell carcinoma in the era of targeted therapy
}

\author{
JUN TEISHIMA $^{1}$, DAIKI MURATA ${ }^{2}$, SHOGO INOUE ${ }^{1}$, TETSUTARO HAYASHI ${ }^{1}$, KOJI \\ MITA $^{2}$, YASUHISA HASEGAWA ${ }^{3}$, MASAO KATO ${ }^{4}$, MITSURU KAJIWARA ${ }^{5}$, MASANOBU \\ SHIGETA $^{6}$, SATOSHI MARUYAMA $^{7}$, HIROYUKI MORIYAMA ${ }^{8}$ and SEIJI FUJIWARA ${ }^{9}$ \\ ${ }^{1}$ Department of Urology, Graduate School of Biomedical and Health Sciences, Hiroshima University, Hiroshima 734-8551; \\ ${ }^{2}$ Department of Urology, Hiroshima-City Asa Citizens Hospital, Hiroshima 731-0293; ${ }^{3}$ Department of Urology, \\ Fukuyama Medical Center, Fukuyama, Hiroshima 720-8520; ${ }^{4}$ Department of Urology, Hiroshima General Hospital, \\ Hatsukaichi, Hiroshima 738-8503; ${ }^{5}$ Department of Urology, Hiroshima Prefectural Hospital, Hiroshima 734-8530; \\ ${ }^{6}$ Department of Urology, Kure Medical Center and Chugoku Cancer Center, Kure, Hiroshima 737-0023; \\ ${ }^{7}$ Department of Urology, Miyoshi Central Hospital, Miyoshi, Tokushima 728-8502; ${ }^{8}$ Department of Urology, \\ Onomichi General Hospital, Onomichi, Hiroshima 722-8508; ${ }^{9}$ Department of Urology, \\ Higashi-Hiroshima Medical Center, Higashi-Hiroshima, Hiroshima 739-0041, Japan
}

Received October 12, 2019; Accepted March 4, 2020

DOI: $10.3892 / \operatorname{mco} .2020 .2020$

\begin{abstract}
The present study investigated the outcomes of targeted therapy for elderly patients with metastatic renal cell carcinoma (mRCC). A total of 277 patients with $\mathrm{mRCC}$ who were treated with tyrosine kinase inhibitor as a first-line therapy from January 2008 to May 2018 were retrospectively investigated by reviewing clinicopathological data. Patients 75 years or older were classified into the older-aged group $(n=55)$ while all others were classified into the younger-aged group $(n=222)$. The preoperative clinicopathological characteristics and the overall survival (OS) rate for these two groups were subsequently compared. The median age in the older- and younger-aged groups was 78 and 63 years $(\mathrm{P}<0.0001)$, respectively. A total of 7,42 and 6 cases in the older-aged group and 46, 118 and 58 cases in the younger-aged group were classified into favorable, intermediate, and poor risk groups, respectively. The rate of patients with cardiovascular diseases (29.1\%) and malignant diseases other than RCC (20.0\%) was significantly higher in the older-aged group compared with the younger-aged group (6.8\%; $\mathrm{P}<0.0001$ and $7.2 \% ; \mathrm{P}=0.0042$, respectively). There was a significant improvement in the OS rate for patients beginning targeted therapy after 2011 compared with those starting therapy prior to 2010 . The $50 \%$ OS rate in patients starting targeted therapy before 2010 and after 2011 was, respectively,
\end{abstract}

Correspondence to: Dr Jun Teishima, Department of Urology, Graduate School of Biomedical and Health Sciences, Hiroshima University, 1-2-3 Kasumi, Minamiku, Hiroshima 734-8551, Japan

E-mail: teishima@hiroshima-u.ac.jp

Key words: metastatic renal cell carcinoma, older-aged patients, overall survival, targeted therapy
17.1 and 38.6 months for the older-aged group $(\mathrm{P}=0.0066)$, while there was no significant difference for the younger-aged group ( $\mathrm{P}=0.1441 ; 50 \%$ OS; 35.9 vs. 30.5 months). The results of the present study indicated that the prognosis for older patients has improved since the introduction of targeted therapy.

\section{Introduction}

While screening using abdominal ultrasonographic examination has been widely used for early-stage renal cell carcinoma (RCC), up to approximately $20-30 \%$ of RCC patients have metastases at initial presentation (1). The introduction of targeted agents has enabled physicians to improve prognosis over the past decade compared with that for patients treated with cytokine therapy (2). Furthermore, previous research has demonstrated that the prognosis in the later period of the era of targeted therapy was better than that in the initial period (3).

Aging is associated with an increased risk of developing various malignant neoplasms, including RCC (4). RCC is most frequently detected between the ages of 60 and 70 years, and more than $25 \%$ of newly diagnosed RCC patients are older than 75 (5). Greater care should be taken when planning the therapeutic strategy for older patients regardless of systemic therapy or surgical treatment because they have potential comorbidities. It is also very important to clarify the background and prognosis for mRCC patients, who are more elderly. Therefore, we investigated the characteristics before treatment and the outcomes of targeted therapy for older patients with $\mathrm{mRCC}$ and compared the results with those for a younger patients.

\section{Patients and methods}

Two hundred and seventy-seven patients with metastatic renal cell carcinoma (mRCC) who were treated with 
Table I. Patient characteristics.

\begin{tabular}{|c|c|c|c|c|}
\hline Variables & $\begin{array}{c}<75 \text { years }(\mathrm{n}=222) \\
\mathrm{n}(\%)\end{array}$ & $\begin{array}{c}\geq 75 \text { years }(\mathrm{n}=55) \\
\mathrm{n}(\%)\end{array}$ & P-value & $\begin{array}{c}\text { Total }(\mathrm{n}=277) \\
\mathrm{n}(\%)\end{array}$ \\
\hline Sex & & & 0.3430 & \\
\hline Male & $182(82.0)$ & $42(76.4)$ & & 224 (80.9) \\
\hline Female & $40(18.0)$ & $13(23.6)$ & & $53(19.1)$ \\
\hline Pathology & & & 0.4251 & \\
\hline Clear & $170(76.6)$ & $46(83.6)$ & & $216(78.0)$ \\
\hline Non-clear & $22(9.9)$ & $5(9.1)$ & & $27(9.7)$ \\
\hline Unknown & $30(13.5)$ & $4(7.3)$ & & $34(12.3)$ \\
\hline Karnofsky PS & & & 0.4460 & \\
\hline$\geq 80 \%$ & 203 (91.4) & $52(94.5)$ & & $255(92.1)$ \\
\hline$<80 \%$ & $19(8.6)$ & $3(5.5)$ & & $22(7.9)$ \\
\hline IMDC risk & & & 0.0067 & \\
\hline Favorable & $46(20.7)$ & 7 (12.7) & & $53(19.1)$ \\
\hline Intermediate & $118(53.2)$ & $42(76.4)$ & & $160(57.8)$ \\
\hline Poor & $58(26.1)$ & $6(10.9)$ & & $64(23.1)$ \\
\hline \multicolumn{5}{|l|}{ Metastatic site } \\
\hline Lung & $149(67.1)$ & $37(67.3)$ & 0.9825 & $186(67.2)$ \\
\hline Lymph node & $71(32.0)$ & $12(21.8)$ & 0.1407 & $83(30.0)$ \\
\hline Liver & $26(11.7)$ & $9(16.4)$ & 0.3526 & 35 (12.6) \\
\hline Bone & $59(26.6)$ & $13(23.6)$ & 0.6563 & $72(26.0)$ \\
\hline Adrenal gland & $23(10.4)$ & $6(10.9)$ & 0.9053 & $29(10.5)$ \\
\hline Ipsilateral kidney & $17(7.7)$ & $4(7.3)$ & 0.9231 & $21(7.6)$ \\
\hline$\geq 2$ organs & $107(48.2)$ & $25(45.5)$ & 0.7153 & $132(47.7)$ \\
\hline Prior nephrectomy & & & 0.5194 & \\
\hline Radical & $102(45.9)$ & $30(54.5)$ & & $132(47.7)$ \\
\hline Cytoreductive & $76(34.2)$ & $16(29.1)$ & & $92(33.2)$ \\
\hline None & $44(19.8)$ & $9(16.4)$ & & $53(19.1)$ \\
\hline First-line agent & & & 0.0027 & \\
\hline Sunitinib & $148(66.7)$ & $23(41.8)$ & & $171(61.7)$ \\
\hline Pazopanib & $12(5.4)$ & $4(7.3)$ & & $16(5.8)$ \\
\hline Sorafenib & $62(27.9)$ & $28(50.9)$ & & $90(32.5)$ \\
\hline Prior cytokine therapy & & & 0.1901 & \\
\hline$(-)$ & $193(86.9)$ & $44(80.0)$ & & $237(85.6)$ \\
\hline$(+)$ & $29(13.1)$ & $11(20.0)$ & & $40(14.4)$ \\
\hline Subsequent nivolumab therapy & & & 0.9331 & \\
\hline$(-)$ & $201(90.5)$ & $50(90.9)$ & & $251(90.6)$ \\
\hline$(+)$ & $21(9.5)$ & $5(9.1)$ & & $26(9.4)$ \\
\hline
\end{tabular}

tyrosine kinase inhibitor (TKI) as the first-line therapy at our institute and other hospitals in Hiroshima Prefecture in Japan from January 2008 to May 2018 were retrospectively investigated by reviewing clinicopathological data. Ethical approval was given by the Ethical Committee of Hiroshima University (Hiroshima, Japan) (Allowance notification number: E-45), and after that, it was given by the committee at each collaborative institute. In accordance with the previous study (6) patients aged 75 years or older were classified into the older-aged group, and the others were classified into the younger-aged group. Clinical and pathological data including age, sex, histological finding, metastasis status, comorbidities, selection of and severe adverse events of first-line agent, prior nephrectomy, Karnofsky performance status, and international $\mathrm{mRCC}$ database consortium (IMDC) risk were collected for all patients, and the distribution of these parameters for each group was compared. The overall survival (OS) rate of each group was analyzed by further classification in accordance with their first-line agent and the period in which targeted therapy was started.

Statistical analysis. Differences in the distribution of variables among groups were analyzed using a Chi-square test for categorical variables and a Mann-Whitney U test for 
Table II. Comparison of comorbidities.

\begin{tabular}{|c|c|c|c|c|}
\hline Variables & $\begin{array}{c}<75 \text { years }(\mathrm{n}=222) \\
\mathrm{n}(\%)\end{array}$ & $\begin{array}{c}\geq 75 \text { years }(\mathrm{n}=55) \\
\mathrm{n}(\%)\end{array}$ & P-value & $\begin{array}{c}\text { Total }(\mathrm{n}=277) \\
\mathrm{n}(\%)\end{array}$ \\
\hline Hypertension & $46(20.7)$ & $19(34.5)$ & 0.0303 & $65(23.5)$ \\
\hline Ischemic heart disease/heart failure & $6(2.7)$ & $6(10.9)$ & 0.0074 & $12(4.3)$ \\
\hline Arrhythmia & $6(2.7)$ & $7(12.7)$ & 0.0016 & $13(4.7)$ \\
\hline Vascular disease & $3(1.4)$ & $3(5.5)$ & 0.0613 & $6(2.2)$ \\
\hline Cerebrovascular disease & $5(2.5)$ & $3(5.5)$ & 0.2043 & $8(2.9)$ \\
\hline Respiratory disease & $8(3.6)$ & $2(3.6)$ & 0.9907 & $10(3.6)$ \\
\hline Renal dysfunction & $8(3.6)$ & $5(9.1)$ & 0.0850 & $13(4.7)$ \\
\hline Other malignant neoplasm & $16(7.2)$ & $11(20.0)$ & 0.0042 & $27(9.7)$ \\
\hline
\end{tabular}

Table III. Discontinuation of first-line agents caused by adverse events.

\begin{tabular}{|c|c|c|c|c|}
\hline Variables & $\begin{array}{c}<75 \text { years }(\mathrm{n}=222) \\
\mathrm{n}(\%)\end{array}$ & $\begin{array}{c}\geq 75 \text { years }(\mathrm{n}=55) \\
\mathrm{n}(\%)\end{array}$ & P-value & $\begin{array}{c}\text { Total }(\mathrm{n}=277) \\
\mathrm{n}(\%)\end{array}$ \\
\hline Cardiovascular event & $5(2.3)$ & $3(5.5)$ & 0.2043 & $8(2.9)$ \\
\hline Respiratory event & $1(0.5)$ & $0(0)$ & 0.6180 & $1(0.4)$ \\
\hline Gastrointestinal event & $10(4.5)$ & $3(5.5)$ & 0.7655 & $13(4.7)$ \\
\hline Bone marrow suppression & $27(12.2)$ & $6(10.9)$ & 0.7973 & $33(11.9)$ \\
\hline Dermatological toxicity & $17(7.7)$ & $4(7.3)$ & 0.9231 & $20(7.2)$ \\
\hline Endocrinological event & $1(0.5)$ & $1(1.8)$ & 0.2835 & $2(0.7)$ \\
\hline Liver/renal dysfunction & $9(4.1)$ & $2(3.6)$ & 0.8871 & $9(3.3)$ \\
\hline Neurological event & $2(0.9)$ & $2(3.6)$ & 0.1279 & $4(1.4)$ \\
\hline General fatigue & $0(0)$ & $2(3.6)$ & 0.0044 & $2(0.7)$ \\
\hline Patient's desire & $9(4.1)$ & $5(9.1)$ & 0.1269 & $5(1.8)$ \\
\hline Total & $65(29.3)$ & $24(43.6)$ & 0.0412 & $89(32.1)$ \\
\hline
\end{tabular}

continuous variables. Tumor responses were determined using an investigator assessment based on the response evaluation criteria in solid tumors (RECIST) version 1.1. The OS rate was determined using the Kaplan-Meier method, and differences between groups were analyzed using log-rank testing. All statistical analyses were conducted using Statview 5.0 software (Abacus Concepts, Inc.). $\mathrm{P}<0.05$ was considered statistically significant.

\section{Results}

This study cohort consisted of 277 cases of targeted therapy for mRCC. A total of 55 cases (19.9\%) were classified into the older-aged group, and the other 222 cases (80.1\%) were classified into the younger-aged group. The characteristics of the cases are listed in Table I. The rates of cases categorized as poor risk on the basis of IMDC risk criteria and of those treated with sorafenib were significantly higher in the older-aged group than in the younger-aged group while those treated with sunitinib were significantly lower. Median age in the older- and younger-aged groups was 78 and 63 years. The rate of patients with cardiovascular diseases and malignant diseases including hypertension, ischemic heart disease, heart failure, and arrhythmia besides RCC in the older-aged group was significantly higher than that in the younger-aged group (Table II). The 50\% OS rate for the entire cohort was 33.8 months, and there was no significant difference in the rate regardless of the choice of first-line agent or the existence of prior cytokine therapy (Fig. 1). The rate of cases in which first-line therapy was stopped because of adverse events was significantly higher in the higher-aged group (Table III). There was no significant difference in the OS rate between the higher- and younger-aged groups regardless of the choice of first-line agent (Fig. 2). Table IV compares the characteristics of the patients on the basis of the period in which they started first-line TKI: Either 2008-2010 or 2011-2018. In the latter phase, the rates of patients treated with first-line sunitinib or pazopanib and/or subsequent nivolumab were significantly higher than those in the earlier phase while the rates of patients treated with sorafenib and/or prior cytokine therapy were significantly lower. For all patients, for those treated with sunitinib as a first-line therapy and for those without prior cytokine therapy, there was a significant improvement in the OS rate for patients starting therapy after 2011 compared with the rate for those starting it before 2010 (Fig. 3A-C). The $50 \%$ OS rate in patients starting targeted therapy before 2010 and after 2011 was respectively 17.1 and 38.6 months for the older-aged group $(\mathrm{P}=0.0066)$, while there was no significant 


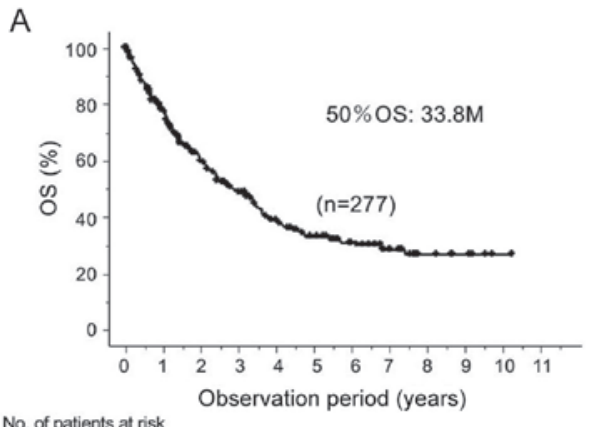

No. of patients at risk

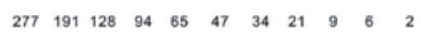

C

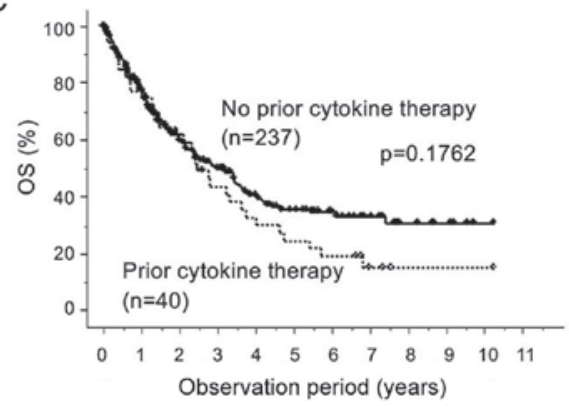

No. of patients at risk

$\begin{array}{lrrrrrrrrrrr}\text { No prior cytokine therapy } & 237 & 160 & 104 & 78 & 53 & 38 & 27 & 17 & 8 & 5 & 1 \\ \text { Prior cytokine therapy } & 40 & 31 & 24 & 16 & 12 & 9 & 7 & 4 & 1 & 1 & 1\end{array}$

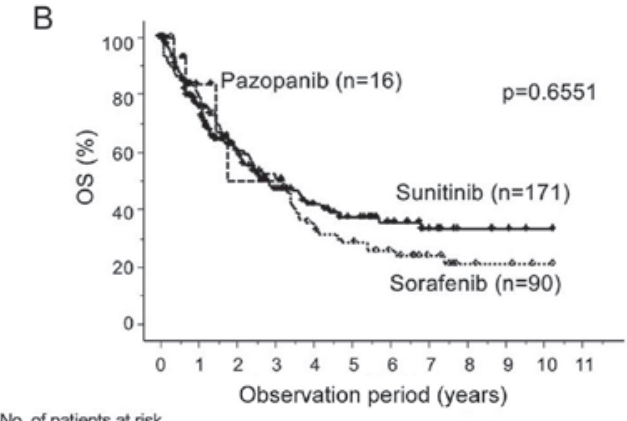

No. of patients at risk

$\begin{array}{llllllllllll}\text { Sunitinib } & 171 & 113 & 74 & 52 & 39 & 27 & 18 & 11 & 5 & 3 & 1\end{array}$

$\begin{array}{lrrrrrrrrrrr}\text { Pazopanib } & 16 & 6 & 3 & 1 & & & & & & & \\ \text { Sorafenib } & 90 & 72 & 51 & 41 & 26 & 20 & 16 & 10 & 4 & 3 & 1\end{array}$

Figure 1. OS rate for (A) all cases, (B) groups divided in accordance with choice of first-line agent, and (C) groups divided in accordance with existence of prior cytokine therapy. OS, overall survival.

A

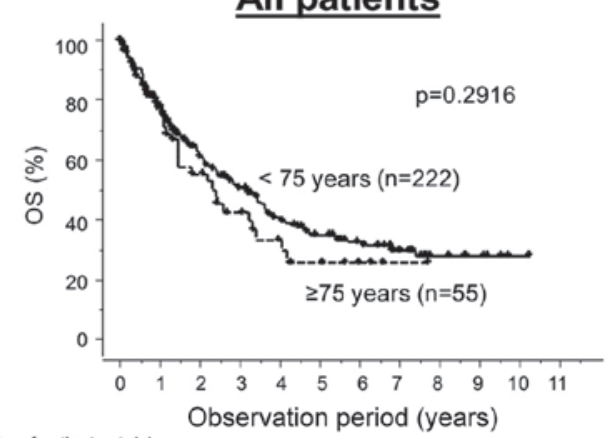

No. of patients at risk

$\begin{array}{lllllllllllll}<5 \text { years } & 222 & 154 & 105 & 79 & 55 & 41 & 30 & 20 & 9 & 6 & 2\end{array}$

$\begin{array}{llllllllll}275 & \text { years } & 55 & 37 & 23 & 15 & 10 & 6 & 4 & 1\end{array}$

C

Sunitinib

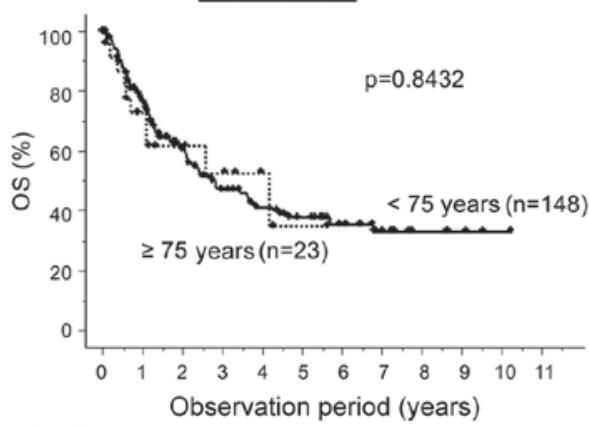

No. of patients at risk

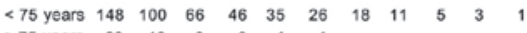

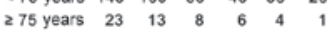

B

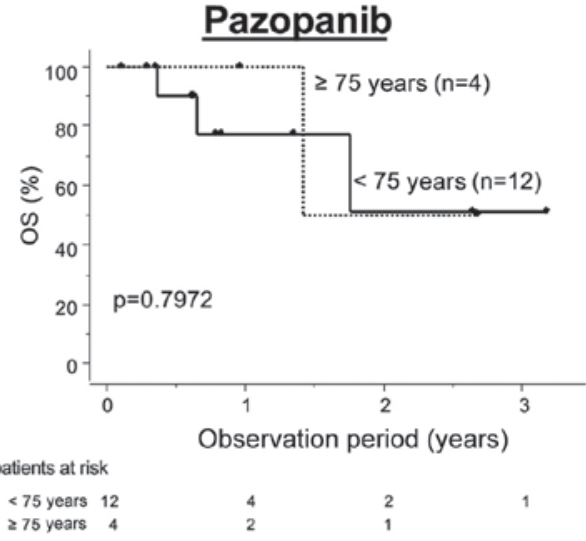

$\mathrm{D}$

\section{Sorafenib}

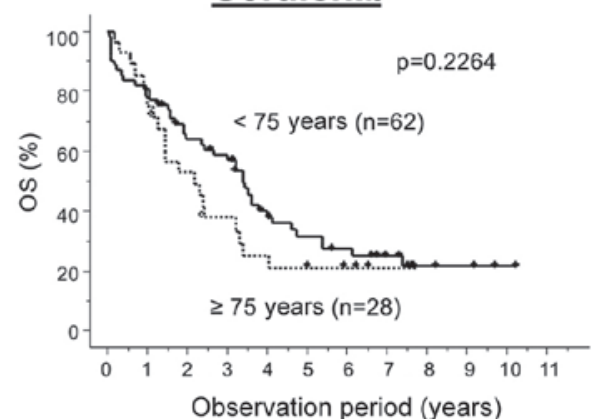

No. of patients at risk

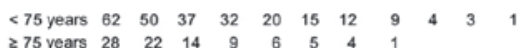

Figure 2. OS rate classified on the basis of patients' age (younger or older) for (A) all cases and for those treated with (B) pazopanib, (C) sunitinib, or (D) sorafenib as first-line agent. OS, overall survival. 
Table IV. Characteristics of patients comparing at timing starting first-line TKI.

\begin{tabular}{|c|c|c|c|c|}
\hline Variables & $\begin{array}{c}2007-2010(\mathrm{n}=97) \\
\mathrm{n}(\%)\end{array}$ & $\begin{array}{c}2011-2018(\mathrm{n}=180) \\
\mathrm{n}(\%)\end{array}$ & P-value & $\begin{array}{c}\text { Total }(\mathrm{n}=277) \\
\mathrm{n}(\%)\end{array}$ \\
\hline Age (years) & & & 0.4755 & \\
\hline$\geq 75$ & $17(17.5)$ & $38(21.1)$ & & 55 (19.9) \\
\hline$<75$ & $80(82.5)$ & $142(78.9)$ & & $222(80.1)$ \\
\hline Sex & & & 0.0750 & \\
\hline Male & $84(86.6)$ & $140(77.8)$ & & $224(80.9)$ \\
\hline Female & $13(13.4)$ & $40(22.2)$ & & $53(19.1)$ \\
\hline Pathology & & & 0.0190 & \\
\hline Clear & $71(73.2)$ & $145(80.6)$ & & $216(78.0)$ \\
\hline Non-clear & $7(7.2)$ & $20(11.1)$ & & $27(9.7)$ \\
\hline Unknown & $19(19.6)$ & $15(8.3)$ & & $34(12.3)$ \\
\hline Karnofsky PS & & & 0.5460 & \\
\hline$\geq 80 \%$ & $88(90.7)$ & $167(92.8)$ & & $255(92.1)$ \\
\hline$<80 \%$ & $9(9.3)$ & $13(7.2)$ & & $22(7.9)$ \\
\hline IMDC risk & & & 0.8991 & \\
\hline Favorable & $20(20.6)$ & 33 (18.3) & & $53(19.1)$ \\
\hline Intermediate & $55(56.7)$ & $105(58.3)$ & & $160(57.8)$ \\
\hline Poor & $22(22.7)$ & $42(23.3)$ & & $64(23.1)$ \\
\hline \multicolumn{5}{|l|}{ Metastatic site } \\
\hline Lung & $65(67.0)$ & $121(67.2)$ & 0.9714 & $186(67.2)$ \\
\hline Lymph node & $28(28.9)$ & $55(30.6)$ & 0.7697 & $83(30.0)$ \\
\hline Liver & $15(15.5)$ & $20(11.1)$ & 0.2983 & 35 (12.6) \\
\hline Bone & 29 (29.9) & 43 (23.9) & 0.2768 & $72(26.0)$ \\
\hline Adrenal gland & $7(7.2)$ & $22(12.2)$ & 0.1943 & $29(10.5)$ \\
\hline Ipsilateral kidney & $6(6.2)$ & $15(8.3)$ & 0.5194 & $21(7.6)$ \\
\hline$\geq 2$ organs & $49(50.5)$ & $83(46.1)$ & 0.4839 & $132(47.7)$ \\
\hline Prior nephrectomy & & & 0.4416 & \\
\hline Radical & $51(52.6)$ & $81(45.0)$ & & $132(47.7)$ \\
\hline Cytoreductive & $28(28.9)$ & $64(35.6)$ & & $92(33.2)$ \\
\hline None & $18(18.6)$ & $35(19.4)$ & & $53(19.1)$ \\
\hline 1st-line agent & & & $<0.0001$ & \\
\hline Sunitinib & $44(45.4)$ & $127(70.6)$ & & $171(61.7)$ \\
\hline Pazopanib & $0(0)$ & $16(8.9)$ & & $16(5.8)$ \\
\hline Sorafenib & $53(54.6)$ & $37(20.6)$ & & $90(32.5)$ \\
\hline Prior cytokine therapy & & & $<0.0001$ & \\
\hline$(-)$ & $69(71.1)$ & $168(93.3)$ & & $237(85.6)$ \\
\hline$(+)$ & $28(28.9)$ & $12(6.7)$ & & $40(14.4)$ \\
\hline Subsequent nivolumab therapy & & & $<0.0001$ & \\
\hline$(-)$ & $97(100)$ & $154(85.6)$ & & $251(90.6)$ \\
\hline$(+)$ & $0(0)$ & $26(14.4)$ & & $26(9.4)$ \\
\hline
\end{tabular}

TKI, tyrosine kinase inhibitor; IMDC, international mRCC database consortium.

difference in the rate for the younger-aged one $(\mathrm{P}=0.1441,50 \%$ OS; 35.9 vs. 30.5 months) (Fig. 3E and F).

\section{Discussion}

In the present study, we assessed the improvement in the prognosis for patients with $\mathrm{mRCC}$ in the earlier and later phases of the era of targeted therapy for all patients and for patients without prior cytokine therapy. The results showed that the prognosis for older patients improved after the introduction of targeted therapy. To the best of our knowledge, this study is the first to demonstrate an improvement in the prognosis for older patients during the later period of targeted therapy compared with that in the initial one. 
A

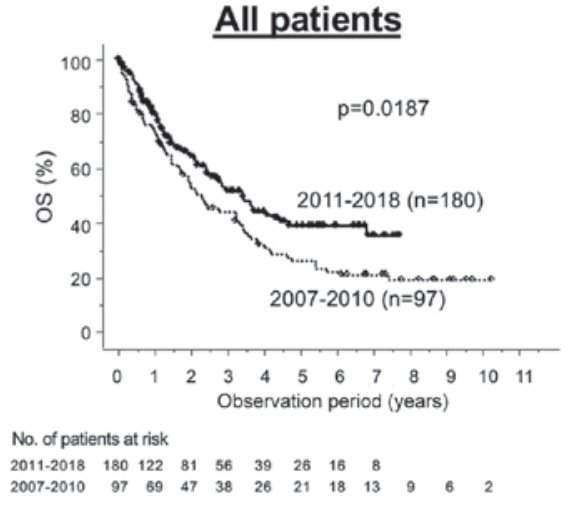

C

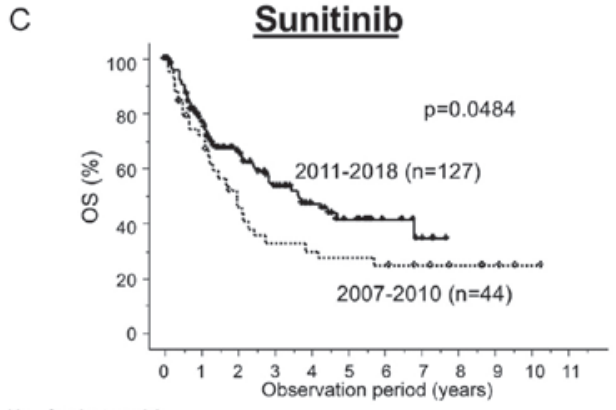

No. of patients at risk

$\begin{array}{rrrrrrrrrrrr}2011-2018 & 127 & 84 & 57 & 40 & 28 & 17 & 9 & 4 & & & \\ 2007-2010 & 44 & 29 & 17 & 12 & 11 & 10 & 9 & 7 & 5 & 3 & 1\end{array}$

$\mathrm{E}$

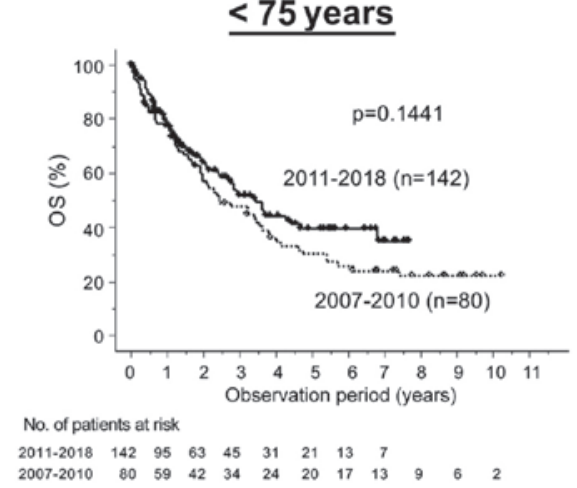

B No prior cytokine therapy

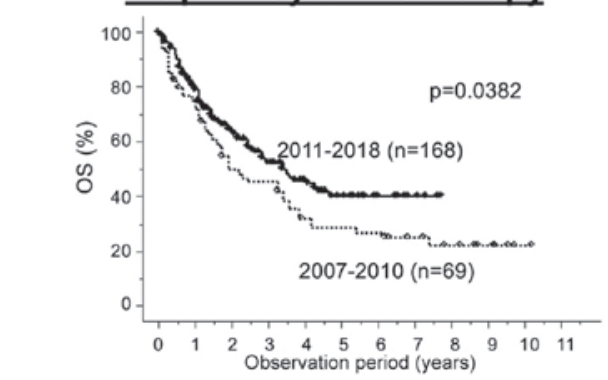

No. of patients at risk

$\begin{array}{rrrrrrrrrrrr}2011-2018 & 168 & 114 & 73 & 50 & 35 & 22 & 12 & 6 & & & \\ 2007-2010 & 69 & 47 & 31 & 28 & 18 & 16 & 15 & 11 & 8 & 5 & 1\end{array}$

D
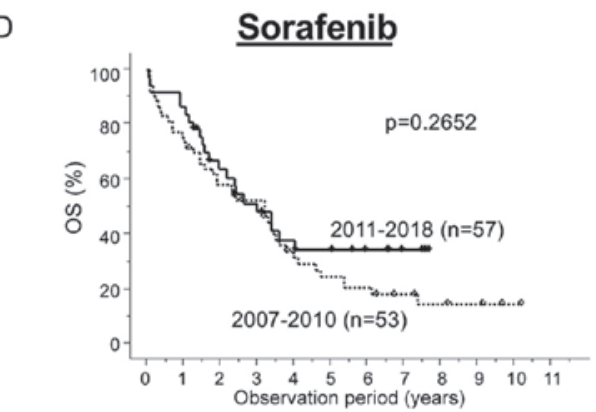

No. of patients at risk

$\begin{array}{cccccccccccc}2011-2018 & 57 & 32 & 21 & 15 & 11 & 9 & 7 & 4 & & & \\ 2007-2010 & 53 & 40 & 30 & 26 & 15 & 11 & 9 & 6 & 4 & 3 & 1\end{array}$

F

$\geqq 75$ years

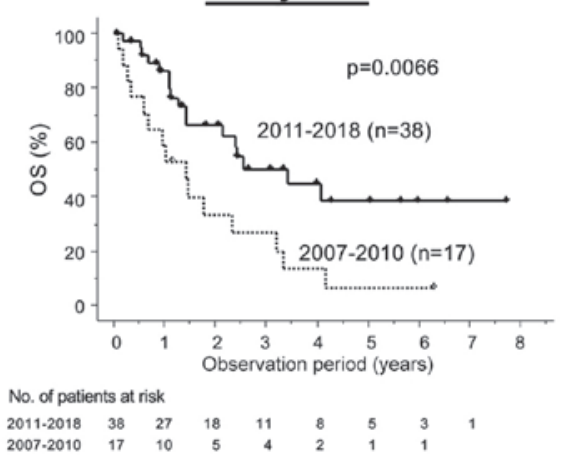

Figure 3. OS rate classified on the basis of when targeted therapy was started (initial period or later period) for (A) all cases, (B) cases without prior cytokine therapy, and cases treated with (C) sunitinib or (D) sorafenib; (E) younger-aged group and (F) Older-aged group. OS, overall survival.

Recently, several randomized control trials have demonstrated the efficacy of immune checkpoint inhibitors (ICIs) and combination regimens including ICIs for mRCC patients (7-10), and as such, many patients with mRCC are being treated with ICI. However, in the CheckMate 025 trials, nivolumab, one of the most common ICIs for mRCC, was reported to be less effective in older patients than in younger ones (7). Moreover, when patients with $\mathrm{mRCC}$ receive ICI therapy, immune-related adverse events (irAEs) are inevitable. Physicians need to assess whether patients can overcome such irAEs. These considerations means that TKI is likely to remain one of the standard options for older patients with mRCC.

We can see an improvement in the OS rate in the entire cohort. We can also see some improvement even in the younger-aged group, but it is not statistically significant. Thus, we hypothesize that this improvement represents outcomes particular to the older-aged group. It is relatively easy to manage younger patients who receive targeted therapy because many of them are generally healthy despite having metastatic RCC. In contrast, many older patients have additional comorbidities (e.g., cardiovascular or respiratory disease), which can prevent them from continuing to receive targeted therapy. Many physicians have now mastered the management of patients who receive targeted therapy in terms of agent choice, agent dose, and adverse events. Therefore, we can see significant improvement in the OS rate, especially for older patients who have more comorbidities.

There are two possible explanations as to why the prognosis for older patients has improved more than that for younger ones. The first is the changes in and increased number of therapeutic options for both first- and second-line therapies. The non-inferiority of pazopanib compared with 
sunitinib as a first-line option and the improvement in progression-free survival due to axitinib therapy compared with sorafenib therapy along with the superior OS rate due to nivolumab therapy as second-line options for $\mathrm{mRCC}$ have been demonstrated by randomized controlled trials $(7,8,11)$. Moreover, these therapies have been recommended as viable first-line and second-line options in several published guidelines $(12,13)$. On the basis of this evidence, they are now covered by the national health insurance system in Japan. In particular, since pazopanib is reported to be relatively tolerable for patients (14), it seems poised to become a viable option for older patients with severe comorbidities. This increase in the number of treatment options enables physicians to choose the best one for each patient in accordance with their characteristics. However, in this study, pazopanib was administered to only four patients in the higher-aged group, so its effect may be limited to the cohort of this study. As more than half of the patients in the initial period received sorafenib as first-line therapy, the change in the rate of sorafenib as a first-line option might provide some insight into the improvement in the OS rate.

The other possible explanation for the improved prognosis for older patients is optimal management of a therapeutic schedule personalized for each patient. Several previous studies have demonstrated the efficacy and safety of various agents [e.g., sunitinib (6,15-18) and sorafenib (19)] for older patients, and another study reported that an alternative schedule of sunitinib treatment provided a greater improvement in the OS rate compared with the standard schedule (20). Since sunitinib was prescribed on the basis of a personalized schedule in the later period, the data from our present study for patients treated with sunitinib is consistent with those reports (Fig. 3C).

The limitation of the present work is that it is a small retrospective study based on real-world data. Physicians were assumed to have taken into account the comorbidity of patients and the tolerability of each agent when the therapeutic option was chosen. Therefore, some patient-selection bias due to the exclusion of patients with very severe comorbidities from targeted therapy is entirely possible. The older-aged group in this study consisted of $19.9 \%$ of the patients, which is a higher rate than in the previous study (21). There might be some differences between countries in terms of the age distribution of patients with $\mathrm{mRCC}$ who undergo systemic therapy. In addition, we have no data of clinical classification based on the data of some special molecules identified by gene analysis. A prospective observation study using a greater amount of data is required to further clarify the characteristics and the prognosis for older patients with mRCC.

We have demonstrated that the prognosis for older patients has improved compared with that when targeted therapy was first introduced. Our data clearly indicate the benefit to older patients of the recent rapid introduction of new agents as therapeutic options for mRCC. It is thus expected that the continuing increase of therapeutic options (including ICIs as well as targeted agents) will lead to further improvement in the prognosis for patients with $\mathrm{mRCC}$ in the coming years. At the same time, we expect that a more personalized therapeutic strategy will be established for older patients that is based on key molecules identified through gene sequencing in addition to conventional predictive factors for prognosis and agent efficacy $(22,23)$ as older patients tend to have more comorbidities than younger ones.

\section{Acknowledgements}

In addition to the authors, the following investigators participated in the study: Dr. Hideo Iwamoto, Kure Medical Center; Dr. Ryo Tasaka, Hiroshima General Hospital; Dr. Koichi Shoji and Dr. Ryoken Yamanaka, Higashi-Hiroshima Medical Center; Shinji Matsuzaki, Fukuyama Medical Center; Dr. Yoshinori Nakano, Onomichi General Hospital; and Dr. Yuki Kohada, Hiroshima Prefectural Hospital.

\section{Funding}

No funding was received.

\section{Availability of data and materials}

The datasets used and/or analyzed during this study are available from the corresponding author on reasonable request.

\section{Authors' contributions}

JT, SI, TH and AM conceived and designed this study. DM, KM, YH, MKat, MKaj, MS, SM, HM and SF acquired the data. JT, SI and TH analyzed the data. JT drafted the manuscript. All authors read and approved the final manuscript.

\section{Ethics approval and consent to participate}

The present study was approved by the Ethical Committee of Hiroshima University (Allowance notification no. E-45) (Hiroshima, Japan). The requirement of informed consent was waived by the Institutional Review Board.

\section{Patient consent for publication}

Not applicable.

\section{Competing interests}

The authors declare that they have no competing interests.

\section{References}

1. Siegel RL, Miller KD and Jemal A: Cancer statistics, 2018. CA Cancer J Clin 68: 7-30, 2018

2. Pal SK, Nelson RA and Vogelzang N: Disease-specific survival in de novo metastatic renal cell carcinoma in the cytokine and targeted therapy era. PLoS One 8: e63341, 2013.

3. Pal SK, Ghate SR, Li N, Swallow E, Peeples M, Zichlin ML, Perez JR, Agarwal N and Vogelzang NJ: Real-world survival outcomes and prognostic factors among patients receiving first targeted therapy for advanced renal cell carcinoma: A SEER-medicare database analysis. Clin Genitourin Cancer 15: e573-e582, 2017

4. Janssen-Heijnen ML, Gondos A, Bray F, Hakulinen T, Brewster DH, Brenner H and Coebergh JW: Clinical relevance of conditional survival of cancer patients in Europe: Age-specific analyses of 13 cancers. J Clin Oncol 28: 2520-2528, 2010.

5. Pal SK, Vanderwalde A, Hurria A and Figlin RA: Systemic therapies for metastatic renal cell carcinoma in older adults. Drugs Aging 28: 635-649, 2011. 
6. Miyake H, Aki R, Matsushita Y, Tamura K, Motoyama D, Ito T, Sugiyama T and Otsuka A: Significance of age in Japanese patients receiving sunitinib as first-line systemic therapy for metastatic renal cell carcinoma: Comparative assessment of efficacy and safety between patients aged $<75$ and $\geq 75$ years. Anticancer Res 38: 3593-3599, 2018.

7. Motzer RJ, Escudier B, McDermott DF, George S, Hammers HJ, Srinivas S, Tykodi SS, Sosman JA, Procopio G, Plimack ER, et al: Nivolumab versus everolimus in advanced renal-cell carcinoma. N Engl J Med 373: 1803-1813, 2015.

8. Motzer RJ, Hutson TE, Cella D, Reeves J, Hawkins R, Guo J, Nathan P, Staehler M, de Souza P, Merchan JR, et al: Pazopanib versus sunitinib in metastatic renal-cell carcinoma. N Engl J Med 369: 722-731, 2013.

9. Motzer RJ, Penkov K, Haanen J, Rini B, Albiges L, Campbell MT, Venugopal B, Kollmannsberger C, Negrier S, Uemura M, et al: Avelumab plus axitinib versus sunitinib for advanced renal-cell carcinoma. N Engl J Med 380: 1103-1115, 2019.

10. Rini BI, Plimack ER, Stus V, Gafanov R, Hawkins R, Nosov D, Pouliot F, Alekseev B, Soulières D, Melichar B, et al: Pembrolizumab plus axitinib versus sunitinib for advanced renal-cell carcinoma. N Engl J Med 380: 1116-1127, 2019.

11. Motzer RJ, Escudier B, Tomczak P, Hutson TE, Michaelson MD, Negrier S, Oudard S, Gore ME, Tarazi J, Hariharan S, et al: Axitinib versus sorafenib as second-line treatment for advanced renal cell carcinoma: Overall survival analysis and updated results from a randomised phase 3 trial. Lancet Oncol 14: $552-562,2013$

12. Ljungberg B, Albiges L, Abu-Ghanem Y, Bensalah K, Dabestani S, Fernández-Pello S, Giles RH, Hofmann F, Hora M, Kuczyk MA, et al: European Association of urology guidelines on renal cell carcinoma: The 2019 Update. Eur Urol 75: 799-810, 2019.

13. NCCN clinical practice guidelines in oncology (NCCN guidelines) Kidney Cancer. https://www.nccn.org/professionals/physician_gls/pdf/kidney.pdf

14. Escudier B, Porta C, Bono P, Powles T, Eisen T, Sternberg CN, Gschwend JE, De Giorgi U, Parikh O, Hawkins R, et al: Randomized, controlled, double-blind, cross-over trial assessing treatment preference for pazopanib versus sunitinib in patients with metastatic renal cell carcinoma: PISCES Study. J Clin Oncol 32: 1412-1418, 2014.
15. De Giorgi U, Scarpi E, Sacco C, Aieta M, Lo Re G, Sava T, Masini C, De Vincenzo F, Baldazzi V, Camerini A, et al: Standard vs. adapted sunitinib regimen in elderly patients with metastatic renal cell cancer: Results from a large retrospective analysis. Clin Genitourin Cancer 12: 182-189, 2014.

16. Hutson TE, Bukowski RM, Rini BI, Gore ME, Larkin JM, Figlin RA, Barrios CH, Escudier B, Lin X, Fly K, et al: Efficacy and safety of sunitinib in elderly patients with metastatic renal cell carcinoma. Br J Cancer 110: 1125-1132, 2014.

17. Brunello A, Basso U, Sacco C, Sava T, De Vivo R, Camerini A, Barile C, Roma A, Maruzzo M, Falci C, et al: Safety and activity of sunitinib in elderly patients ( $\geq 70$ years) with metastatic renal cell carcinoma: A multicenter study. Ann Oncol 24: 336-342, 2013.

18. Poprach A, Lakomy R, Bortlicek Z, Melichar B, Pavlik T, Slaby O, Vyzula R, Svoboda M, Kiss I, Studentova H, et al: Efficacy of sunitinib in elderly patients with metastatic renal cell carcinoma: Data from real-world clinical practice. Drugs Aging 33: 655-663, 2016.

19. Dutcher JP, Tannir N, Bellmunt J and Escudier B: Experience with sorafenib and the elderly patient. Med Oncol 27: 1359-1370, 2010.

20. Atkinson BJ, Kalra S, Wang X, Bathala T, Corn P, Tannir NM and Jonasch E: Clinical outcomes for patients with metastatic renal cell carcinoma treated with alternative sunitinib schedules. J Urol 191: 611-618, 2014.

21. Khambati HK, Choueiri TK, Kollmannsberger CK, North S, Bjarnason GA, Vaishampayan UN, Wood L, Knox JJ, Tan MH, MacKenzie MJ, et al: Efficacy of targeted therapy for metastatic renal cell carcinoma in the elderly patient population. Clin Genitourin Cancer 12: 354-358, 2014

22. Teishima J, Inoue S, Hayashi T and Matsubara A. Current status of prognostic factors in patients with metastatic renal cell carcinoma. Int J Urol 26: 608-617, 2019.

23. De Giorgi U, Procopio G, Giannarelli D, Sabbatini R, Bearz A, Buti S, Basso U, Mitterer M, Ortega C, Bidoli P, et al: Association of systemic inflammation index and body mass index with survival in patients with renal cell cancer treated with nivolumab. Clin Cancer Res 25: 3839-3846, 2019. 